\title{
EFEKTIVITAS PEMBELAJARAN BERDASARKAN MASALAH DALAM MENINGKATKAN AKTIVITAS DAN KEMAMPUAN PEMECAHAN MASALAH MATEMATIKA SISWA SMA
}

\author{
Sumarti \\ SMA Negeri 1 Pekanbaru \\ Email: ssumarti43@gamail.com
}

\begin{abstract}
During teaching and learning process, the students tended to be passive and the class was dominated by the teacher. This situation made the students' activity in learning became low as they just memorized the concepts instead of understood them. This research was aimed at improving students' activity and ability in problem solving in Math through problem-based learning model.This was a classroom action research which was conducted in two cycles. The data of this research was collected through observation sheet and a test. The data gotten then was analyzed descriptively. The result of the research showed that the use of problem-based learning model could improve the first year students' activity and ability of problem solving in Math at SMA Negeri 1 Pekanbaru. Students' activities in completing LKS, asking questions to the teachers and peers, answering questions from the teachers and peers, presenting the result of group discussion and drawing a conclusion had been in very good category. In problem solving, the percentage of the students who had gained the minimum standard of achievement (KKM) improved from $61,30 \%$ in the first cycle into $82,14 \%$ in the second cycle.
\end{abstract}

Keywords: Activity, Ability, Problem solving, Problem-Based Learning

\section{PENDAHULUAN}

Matematika merupakan ilmu universal yang mendasari perkembangan teknologi modern, mempunyai peran penting dalam berbagai disiplin dan mengembangkan daya pikir manusia. Untuk menguasai dan mencipta teknologi di masa depan, diperlukan penguasaan matematika yang kuat sejak dini. Hal ini sejalan dengan tujuan pembelajaran matematika dalam Kurikulum Tingkat Satuan Pendidikan (KTSP) yang menyatakan bahwa pembelajaran matematika memiliki peranan penting, yaitu agar siswa memiliki kemampuan: (1) Memahami konsep matematika, menjelaskan keterkaitan antar konsep dan mengaplikasikan konsep atau algoritma secara luwes, akurat, efisien, dan tepat dalam pemecahan masalah, (2) Menggunakan penalaran pada pola dan sifat, melakukan manipulasi matematika dalam membuat generalisasi, menyusun bukti, atau menjelaskan gagasan dan pernyataan matematika, (3) Memecahkan masalah yang meliputi kemampuan memahami masalah, merancang model matematika, menyelesaikan model dan menafsirkan solusi yang diperoleh, (4) Mengkomunikasikan gagasan dengan simbol, tabel, diagram, atau media lain untuk memperjelas keadaan atau masalah, (5) Memiliki sikap menghargai kegunaan matematika dalam kehidupan, yaitu memiliki rasa ingin tahu, perhatian, dan minat dalam mempelajari matematika, serta sikap ulet dan percaya diri dalam pemecahan masalah (Depdiknas, 2006).

Kenyataan yang ditemui di SMAN I Pekanbaru kelas X.3, hasil belajar matematika siswa masih tergolong rendah. Rendahnya Hasil belajar siswa ini dapat dilihat pada Tabel 1 .

Tabel 1. Hasil Ulangan Harian Siswa Kelas X.3 pada Semester Ganjil Tahun Pelajaran 2010/2011

\begin{tabular}{clc}
\hline $\begin{array}{c}\text { Ulangan } \\
\text { Harian }\end{array}$ & \multicolumn{1}{c}{ Materi Pokok } & $\begin{array}{c}\text { Persentase } \\
\text { Ketuntasan }\end{array}$ \\
\hline 1 & $\begin{array}{l}\text { Bentuk pangkat, } \\
\text { akar dan logaritma }\end{array}$ & $58 \%$ \\
2 & $\begin{array}{l}\text { Persamaan, } \\
\text { pertidaksamaan } \\
\text { dan fungsi kuadrat }\end{array}$ & $55,5 \%$ \\
3 & $\begin{array}{l}\text { Sistem persamaan } \\
\text { linear dan kuadrat } \\
\text { Rata-Rata }\end{array}$ & $53,6 \%$ \\
& $55,7 \%$ \\
\hline
\end{tabular}

Sumber: (Wakil Kepala Sekolah Urusan Kurikulum SMAN 1 Pekanbaru)

Dari Tabel 1 terlihat siswa yang tuntas dari tiga kali ulangan harian rata-rata ketuntasannya hanya $55,7 \%$ yaitu 17 orang dari jumlah siswa 31 orang. Penulis menduga rendahnya hasil belajar siswa merupakan 
implikasi rendahnya kemampuan pemecahan masalah siswa dalam menyelesaikan soal.

Pada proses pembelajaran yang terjadi di dalam kelas aktivitas siswa untuk bertanya, menjawab pertanyaan dan mengemukakan pendapat masih rendah. Hal ini dapat dilihat pada saat proses pembelajaran di kelas hanya satu atau dua siswa saja yang mau bertanya atau memberikan jawaban atas pertanyaan yang diberikan oleh guru. Siswa tidak mau mengemukakan ide-idenya bahkan cenderung diam. Selama ini, pembelajaran matematika di kelas X.3 didominasi oleh guru. Guru belum berpengalaman dan kurang percaya diri dalam menerapkan model-model pembelajaran. Pelajaran diberikan kepada siswa dengan metode ceramah dan tanya jawab. Saat proses belajar mengajar berlangsung pada umumnya siswa kurang aktif dalam mengikuti pelajaran. Arends (Sukadewi dan Sumaryani, 2016 : 19): "It is strange that we expect students to learn yet seldom teach them about learning, we expect students to solve problems yet seldom teach them about problem solving", yang berarti dalam belajar guru selalu menuntut siswa untuk belajar dan jarang memberikan pelajaran tentang bagaimana siswa belajar, guru juga menuntut siswa untuk menyelesaikan masalah, tapi jarang mengajarkan bagaimana siswa seharusnya menyelesaikan masalah.

Guru sebagai salah satu komponen yang menentukan keberhasilan pembelajaran di sekolah terus dituntut untuk menciptakan suasana pembelajaran yang menyenangkan sehingga dapat meningkatkan aktivitas dan kemampuan pemecahan masalah siswa. Salah satu strategi pembelajaran yang diyakini dapat mengatasi permasalahan tersebut yaitu problem-based learning $(P B L)$ atau pembelajaran berdasarkan masalah (PBM), yang merupakan pembelajaran yang dimulai dengan masalah yang terbuka (open-ended) dalam suatu situasi kontekstual, yang prosedur penyelesaiannya tidak terstruktur dengan baik (ill-structured), artinya tidak algoritmis/prosedural.

PBM dipilih karena sesuai dengan tujuan pembelajaran dewasa ini, yaitu memberi banyak kesempatan kepada siswa untuk doing math. PBM merupakan suatu strategi di kelas yang mengorganisasi pembelajaran pada aktivitas pemecahan masalah, memberi kesempatan bagi siswa untuk berpikir kritis, mempresentasikan ide-ide mereka, dan mengkomunikasikan kepada teman sebayanya. Dengan PBM, aktivitas siswa dalam pembelajaran dapat diarahkan untuk menyelesaikan masalah, siswa tidak hanya sekedar mendengarkan, mencatat, kemudian menghafal materi pelajaran, akan tetapi melalui PBM siswa aktif berpikir, berkomunikasi, mencari dan mengolah data, dan akhirnya menyimpulkan.

Rumusan masalah pada penelitian ini adalah (1) Bagaimana proses peningkatan aktivitas siswa dalam pembelajaran matematika melalui model PBM. (2) Bagaimana hasil peningkatan pemecahan masalah matematika siswa dalam pembelajaran matematika melalui model PBM. Penelitian ini bertujuan untuk (1) Mendeskripsikan proses peningkatan aktivitas siswa dalam pembelajaran matematika melalui model PBM. (2) Mendeskripsikan hasil peningkatan kemampuan pemecahan masalah matematis siswa melalui model PBM. Penelitian ini diharapkan bermanfaat: (1) Bagi guru, penerapan PBM dapat dijadikan sebagai salah satu model pembelajaran yang dapat diterapkan dalam pembelajaran matematika di SMAN 1 Pekanbaru. (2) Bagi siswa, penerapan PBM dapat meningkatkan hasil belajar matematika siswa kelas X.3 SMAN 1 Pekanbaru semester ganjil Tahun Pelajaran 2011/2012, pada materi sistem persamaan linear dan pertidaksamaan satu variabel. Bagi sekolah, tindakan yang dilakukan pada penelitian ini diharapkan dapat dijadikan salah satu bahan masukan dalam rangka memperbaiki mutu proses pembelajaran matematika sehingga dapat meningkatkan hasil belajar matematika siswa di SMAN 1 Pekanbaru.

Menurut Hamalik dalam Rohmawati (2015), pembelajaran yang efektif adalah pembelajaran yang menyediakan kesempatan belajar sendiri atau melakukan aktivitas sendiri. Purwati, dkk (2017) menyatakan bahwa dalam interaksi pembelajaran, aktivitas merupakan asas yang sangat penting. Asas aktivitas digunakan dalam semua jenis metode pembelajaran, baik metode mengajar di dalam kelas maupun metode mengajar di luar kelas. Hanya saja penggunaannya dilaksanakan dalam bentuk yang berlainan sesuai dengan tujuan yang hendak dicapai dan disesuaikan pula pada orientasi sekolah yang menggunakan jenis kegiatan itu. 
Montessori dalam Sardiman (2016) menegaskan bahwa anak-anak memiliki kemampuan untuk berkembang sendiri, dan membentuk dirinya sendiri. Pendidik akan berperan sebagai pembimbing dan mengamati bagaimana perkembangan anak-anak didiknya. Pernyataan Montessori ini memberikan petunjuk bahwa yang lebih banyak melakukan aktivitas di dalam pembentukan diri adalah anak itu sendiri, sedang pendidik memberikan bimbingan dan merencanakan segala kegiatan yang akan diperbuat oleh anak didik.

Aktivitas siswa tidak cukup hanya mendengarkan dan mencatat. Menurut Paul B. Diedrich dalam Sardiman (2016) jenis-jenis aktivitas sebagai berikut. (1) Visual activities, misalnya membaca, memperhatikan gambar, demonstrasi, percobaan, dan pekerjaan orang lain. (2) Oral activities, seperti: menyatakan, merumuskan, bertanya, memberi saran, mengeluarkan pendapat, mengadakan wawancara, diskusi, dan interupsi. (3) Listening activities, sebagai contoh mendengarkan uraian, percakapan, diskusi, musik, dan pidato. (4) Writing activities, seperti menulis cerita, karangan laporan, angket, dan menyalin. (5) Drawing activities, misalnya menggambar, membuat grafik, peta, dan diagram. (6) Motor activities, yang termasuk di dalamnya antara lain melakukan percobaan, membuat konstruksi, model, mereparasi, bermain, berkebun dan beternak. (7) Mental activites, sebagai contoh menanggapi, mengingat, memecahkan soal, menganalisa, melihat hubungan dan mengambil keputusan. (8) Emotional activites, seperti menaruh minat, merasa bosan, gembira, bersemangat, bergairah, berani, tenang, dan gugup. Dalam penelitian ini aktivitas siswa yang diamati adalah mengerjakan LKS yang diberikan guru, mengajukan pertanyaan kepada guru/teman, menjawab pertanyaan guru/teman, berdiskusi dengan teman satu kelompok, memberi tanggapan terhadap pendapat kelompok lain, mempresentasikan hasil kerja kelompoknya, dan membuat kesimpulan (mencatat hasil diskusi kelompok).

Menurut teori belajar Gagne yang dikutip oleh Suherman dkk (2003) menyatakan bahwa dalam pembelajaran matematika ada dua objek yang diperoleh siswa, yaitu objek langsung dan objek tak langsung. Objek langsung berupa fakta, keterampilan, konsep, dan aturan.

Sedangkan objek tak langsung antara lain kemampuan menyelidiki dan memecahkan masalah, belajar mandiri dan atau bagaimana semestinya belajar. Pada saat belajar matematika siswa akan menemukan berbagai fakta, keterampilan, konsep, dan aturan tertentu. Untuk dapat berinteraksi dengan keadaan tersebut, siswa harus mempunyai kemampuan menyelidiki, memecahkan masalah, belajar mandiri dan mengetahui bagaimana cara belajar yang tepat.

PBM merupakan penggunaan berbagai macam kecerdasan yang diperlukan untuk melakukan konfrontasi terhadap tantangan dunia nyata, kemampuan untuk menghadapi segala sesuatu yang baru dan kompleksitas yang ada (Tan dalam Rusman, 2010). Karakteristik PBM adalah sebagai berikut. Permasalahan menjadi starting point dalam belajar, permasalahan yang diangkat adalah permasahan yang ada di dunia nyata yang tidak terstruktur, permasalahan membutuhkan perspektif ganda (multiple perspective), permasalahan menantang pengetahuan yang dimiliki oleh siswa, sikap dan kompetensi yang kemudian membutuhkan identifikasi kebutuhan belajar dan bidang baru dalam belajar, belajar pengarahan diri menjadi hal yang utama, pemanfaatan sumber pengetehuan yang beragam, penggunaannya, dan evaluasi sumber informasi merupakan proses yang esensial dalam PBM. Belajar adalah kolaboratif, komunikasi, dan kooperatif, pengembangan keterampilan inkuiri dan pemecahan masalah sama pentingnya dengan penguasaan isi pengetahuan untuk mencari solusi dari sebuah permasalahan. Proses dalam PBM meliputi sintesis dan integrasi dari sebuah proses belajar, PBM melibatkan evaluasi dan review pengalaman siswa dan proses belajar.

Tahapan-tahapan model PBM secara garis besar menurut pandangan Ibrahim dan Nur dalam Trianto (2009) dapat dilihat pada Tabel 2.

Tabel 2. Langkah-Langkah Model Pembelajaran Berdasarkan Masalah

\begin{tabular}{lll}
\hline Fase & \multicolumn{1}{c}{ Indikator } & \multicolumn{1}{c}{ Tingkah Laku Guru } \\
\hline 1 & Orientasi siswa & Guru menjelaskan tujuan \\
& pada masalah & pembelajaran, \\
& & menjelaskan logistik yang \\
& & dibutuhkan, memotivasi \\
& & siswa terlibat pada \\
& & aktivitas pemecahan \\
& & masalah.
\end{tabular}




\begin{tabular}{|c|c|c|}
\hline 2 & $\begin{array}{l}\text { Mengorganisasi } \\
\text { kan siswa untuk } \\
\text { belajar }\end{array}$ & $\begin{array}{l}\text { Guru membantu siswa } \\
\text { mendefinisikan dan } \\
\text { mengorganisasikan tugas } \\
\text { belajar yang berhubungan } \\
\text { dengan masalah tersebut. }\end{array}$ \\
\hline 3 & $\begin{array}{l}\text { Membimbing } \\
\text { penyelidikan } \\
\text { individual } \\
\text { maupun } \\
\text { kelompok }\end{array}$ & $\begin{array}{l}\text { Guru mendorong siswa } \\
\text { untuk mengumpulkan } \\
\text { informasi yang sesuai, } \\
\text { melaksanakan } \\
\text { eksperimen, untuk } \\
\text { mendapatkan penjelasan } \\
\text { dan pemecahan masalah. }\end{array}$ \\
\hline 4 & $\begin{array}{l}\text { Mengembangka } \\
\mathrm{n} \text { dan } \\
\text { menyajikan } \\
\text { hasil karya }\end{array}$ & $\begin{array}{l}\text { Guru membantu siswa } \\
\text { dalam merencanakan dan } \\
\text { menyiapkan karya yang } \\
\text { sesuai seperti laporan, dan } \\
\text { membantu mereka untuk } \\
\text { berbagi tugas dengan } \\
\text { temannya. }\end{array}$ \\
\hline 5 & $\begin{array}{l}\text { Menganalisis } \\
\text { dan } \\
\text { mengevaluasi } \\
\text { proses } \\
\text { pemecahan } \\
\text { masalah }\end{array}$ & $\begin{array}{l}\text { Guru membantu siswa } \\
\text { untuk melakukan refleksi } \\
\text { atau evaluasi terhadap } \\
\text { penyelidikan mereka dan } \\
\text { proses yang mereka } \\
\text { gunakan. }\end{array}$ \\
\hline
\end{tabular}

\section{METODE}

Jenis penelitian yang dilaksanakan adalah penelitian tindakan kelas (classroom action research), yaitu suatu penelitian reflektif oleh pelaku tindakan yang dilakukan oleh guru sendiri untuk memperbaiki proses pembelajaran yang menjadi tanggungjawabnya. Tindakan yang dilakukan bertujuan untuk meningkatkan hasil belajar siswa khususnya pada materi sistem persamaan linear dan pertidaksamaan satu variabel serta memperbaiki kondisi pembelajaran yang penulis lakukan. Lokasi penelitian adalah SMA Negeri 1 Pekanbaru Jalan Sultan Syarif Qasim No. 59 Kecamatan Lima Puluh Kota Pekanbaru Propinsi Riau.

Subjek penelitian adalah siswa kelas X.3 SMA Negeri 1 Pekanbaru sebanyak 31 orang, terdiri dari 13 orang laki-laki dan 18 orang perempuan. Penelitian ini dilaksanakan pada pembelajaran semester ganjil Tahun Ajaran 2011/2012 pada materi sistem persamaan linear dan pertidaksamaan satu variabel dengan menggunakan model Pembelajaran Berdasarkan Masalah. Penelitian yang dilakukan mengacu pada model Kemmis Stephan \& Mc. Taggart dalam Arikunto (2012). Penelitian ini dilaksanakan dalam dua siklus, setiap siklus terdiri dari empat tahap, yaitu: (1) menyusun rancangan/perencanaan penelitian, melaksanakan tindakan, (3) melakukan pengamatan, dan (4) melakukan refleksi.
Instrumen dalam penelitian ini terdiri dari: (1) perangkat pembelajaran : Rencana Pelaksanaan Pembelajaran (RPP), Lembar Kerja Siswa (LKS), (2) tes, terdiri dari tes kemampuan pemecahan masalah matematika siklus I dan siklus II, (3) lembar pengamatan. Data yang diperlukan pada penelitian ini adalah data tentang aktivitas siswa selama proses pembelajaran berlangsung dan data tes kemampuan pemecahan masalah matematika.

Teknik analisis data yang digunakan adalah analisis deskriptif yang bertujuan untuk mendeskripsikan data tentang aktivitas siswa selama proses pembelajaran dan data tentang ketuntasan hasil belajar matematika pada materi pokok sistem persamaan linear dan pertidaksamaan satu variabel. Analisis data tentang aktivitas siswa didasarkan dari hasil lembar pengamatan selama pelaksanaan tindakan. Analisis data kemampuan pemecahan masalah matematika siswa diperoleh dari tes kemampuan pemecahan masalah pada tiap akhir siklus. Ketuntasan tes hasil belajar siswa dianalisa berdasarkan Kriteria Ketuntasan Minimal (KKM). Siswa dikatakan tuntas belajarnya apabila mendapat nilai diatas atau sama dengan KKM ( $\geq 70)$, sesuai dengan KKM mata pelajaran matematika kelas X SMA Negeri I Pekanbaru.

\section{HASIL DAN PEMBAHASAN}

Hasil penelitian yang diperoleh setelah tindakan dilaksanakan dari dua siklus menunjukkan adanya perubahan peningkatan aktivitas dan kemampuan pemecahan masalah matematika siswa melalui model pembelajaran berdasarkan masalah.

Pada siklus I pembelajaran dilaksanakan berdasarkan RPP 1, RPP 2 dan RPP 3, sesuai dengan silabus. Pelaksanaan pada siklus I dibagi dalam tiga kali pertemuan yaitu pada hari Selasa tanggal 1 November 2011, hari Kamis tanggal 3 November 2011 dan hari Selasa tanggal 8 November 2011, dengan alokasi waktu 2 x 45 menit tiap pertemuan. Tes hasil belajar kemampuan pemecahan masalah matematika siklus I dilaksanakan pada hari Kamis tanggal 10 November 2011. Data aktivitas siswa selama pembelajaran berlangsung berdasarkan pengamatan observer dapat di lihat pada Tabel 3. 
Tabel 3. Hasil Observasi Aktivitas Siswa Pada Siklus I

\begin{tabular}{lccc}
\hline \multirow{1}{*}{\multicolumn{1}{c}{ Indikator }} & \multicolumn{3}{c}{ Pertemuan ke } \\
& \multicolumn{2}{c}{ (Jumlah dan \%) } \\
\cline { 2 - 4 } & $\mathbf{1}$ & $\mathbf{2}$ & $\mathbf{3}$ \\
\hline Mengerjakan LKS yang & 17 & 21 & 25 \\
diberikan guru & $(61)$ & $(68)$ & $(83)$ \\
Mengajukan pertanyaan kepada & 3 & 4 & 5 \\
guru/teman & $(11)$ & $(14)$ & $(17)$ \\
Menjawab pertanyaan & 6 & 7 & 7 \\
guru/teman & $(21)$ & $(23)$ & $(23)$ \\
Berdiskusi dengan teman satu & 11 & 15 & 16 \\
kelompok & $(39)$ & $(48)$ & $(53)$ \\
Memberi tanggapan terhadap & 4 & 5 & 7 \\
pendapat kelompok lain & $(14)$ & $(16)$ & $(23)$ \\
Mempresentasikan hasil kerja & 5 & 7 & 8 \\
kelompoknya & $(18)$ & $(23)$ & $(27)$ \\
Membuat kesimpulan (mencatat & 15 & 20 & 23 \\
hasil diskusi kelompok) & $(54)$ & $(65)$ & $(77)$ \\
Jumlah kehadiran siswa & 28 & 31 & 30 \\
\hline
\end{tabular}

Dari Tabel 3, terlihat bahwa setelah dilakukan tindakan pada siklus I aktivitas siswa secara umum meningkat, namun belum mencapai kriteria yang ditetapkan sebelumnya. Hanya dua aktivitas yang telah mencapai kriteria yang ditetapkan sebelumnya yaitu: megerjakan LKS yang diberikan guru dan membuat kesimpulan. Hal ini disebabkan karena siswa belum terbiasa dengan model pembelajaran berdasarkan masalah.

Setelah dilakukan tes siklus I penskoran tes kemampuan pemecahan masalah matematika berpedoman pada penskoran yang diadopsi dan dimodifikasi dari pendapat Szetea, Walter dan Nicol, Cynthia dalam Evaluating Problem Solving in Mathematics Educational Leadership, May 1992 :42-45, diuraikan menjadi tiga skala. (a) pemahaman masalah, (b) pemecahan masalah, dan (c) menjawab masalah. Data ketuntasan tes hasil belajar kemampuan pemecahan masalah matematika siklus I dapat dilihat pada Tabel 4.

Tabel 4. Pesentase ketuntasan Tes Hasil Belajar Kemampuan PemecahanMasalah Matematika siswa Siklus I

\begin{tabular}{cccccc}
\hline \multirow{2}{*}{ Siklus } & \multicolumn{2}{c}{$\begin{array}{c}\text { Siswa Mencapai } \\
\text { Nilai } \geq 70\end{array}$} & \multicolumn{2}{c}{$\begin{array}{c}\text { Siswa Mencapai } \\
\text { Nilai }<\text { 70 }\end{array}$} & $\begin{array}{c}\text { Rata- } \\
\text { Rata }\end{array}$ \\
\cline { 2 - 5 } & Jumlah & Persen & Jumlah & Persen & Nilai \\
\hline I & 19 & 61,30 & 12 & 38,70 & 72,00 \\
\hline
\end{tabular}

Berdasarkan Tabel 4, terlihat bahwa hasil belajar kemampuan pemecahan masalah matematika siswa belum mencapai hasil yang diharapkan. Hal ini disebabkan karena siswa belum beradaptasi dengan model pembelajaran yang diterapkan. Prosedur kegiatan yang telah dirancang dalam RPP dan LKS kurang dimaknai oleh siswa sebagai kemampuan pemecahan masalah matematika. Siswa masih banyak yang belum mengerti dan memahami soal-soal yang diberikan dalam LKS. Masih banyak siswa yang mengalami kesulitan dalam menyelesaikan masalah yang menggunakan perhitungan. Dari segi pemahaman soal terlihat bahwa pada sebagian siswa belum mampu menginterpretasikan soal dengan benar. Dalam perencanaan penyelesaian soal, sebagian siswa membuat rencana srategi penyelesaian kurang relevan dengan alur pemahaman materi, sehingga tidak mampu menyelesaikan soal dengan baik. Dalam menyelesaikan soal siswa masih terkendala dengan urutan langkah yang kurang terkonsep dengan baik. Terkadang prosedur yang dilakukan siswa sudah benar, namun jawaban masih salah dalam menyederhanakan bentuk penyelesaian. Pemeriksaan hanya dilakukan dalam bentuk perhitungan, sehingga belum mampu menguji kebenaran dari hasil yang didapatkan. Setelah selesai semua kegiatan pada siklus I, peneliti berkolaborasi dengan observer melakukan refleksi terhadap aktivitas dan kemampuan pemecahan masalah matematika siswa.

Berdasarkan hasil refleksi yang telah dilakukan pada siklus I dapat dilihat bahwa peningkatan aktivitas dan kemampuan pemecahan masalah matematika siswa belum mencapai hasil kategori yang ditetapkan. Untuk itu peneliti bersama observer mengambil kesimpulan bahwa penelitian dilanjutkan pada siklus II dengan perbaikan atau tambahan tindakan yang dilakukan pada siklus II, yaitu: (1) seluruh siswa diberi tugas mempersiapkan satu pertanyaan, (2) peneliti bersama observer akan lebih intensif memantau dan membantu siswa yang masih pasif dikelompoknya, (3) tiap ketua kelompok ditugaskan agar membagi tugas pada anggota kelompoknya sehingga semua anggota kelompok terlibat dalam diskusi, (4) pembuatan LKS agar mengarah pada tuntunan dan bimbingan secara berstruktur.

Pelaksanaan tindakan pada siklus II dilakukan dalam tiga kali pertemuan yaitu pada hari Selasa tanggal 15 November 2011, hari Kamis tanggal 17 November 2011 dan hari Selasa tanggal 22 November 2011. Tes hasil belajar siklus II dilaksanakan pada hari Kamis tanggal 24 November 2011. Data aktivitas dan 
hasil belajar siswa selama pembelajaran siklus II berlangsung dapat dilihat pada Tabel 5 dan Tabel 6.

Tabel 5. Hasil Pengamatan Aktivitas Siswa Pada Siklus II

\begin{tabular}{|c|c|c|c|c|}
\hline \multirow{2}{*}{ No } & \multirow{2}{*}{ Indikator } & \multicolumn{3}{|c|}{$\begin{array}{l}\text { Pertemuan ke - } \\
\text { (Jumlah dan \%) }\end{array}$} \\
\hline & & 1 & 2 & 3 \\
\hline 1. & $\begin{array}{l}\text { Mengerjakan LKS } \\
\text { yang diberikan } \\
\text { guru }\end{array}$ & $\begin{array}{c}30 \\
(100)\end{array}$ & $\begin{array}{c}30 \\
(100)\end{array}$ & $\begin{array}{c}29 \\
(100)\end{array}$ \\
\hline 2. & $\begin{array}{l}\text { Mengajukan } \\
\text { pertanyaan kepada } \\
\text { guru/teman }\end{array}$ & $\begin{array}{c}29 \\
(97)\end{array}$ & $\begin{array}{c}30 \\
(100)\end{array}$ & $\begin{array}{c}29 \\
(100)\end{array}$ \\
\hline 3. & $\begin{array}{l}\text { Menjawab } \\
\text { pertanyaan } \\
\text { guru/teman }\end{array}$ & $\begin{array}{c}24 \\
(80)\end{array}$ & $\begin{array}{c}26 \\
(87)\end{array}$ & $\begin{array}{l}27 \\
(93)\end{array}$ \\
\hline 4. & $\begin{array}{l}\text { Berdiskusi dengan } \\
\text { teman satu } \\
\text { kelompok }\end{array}$ & $\begin{array}{l}19 \\
(63)\end{array}$ & $\begin{array}{c}23 \\
(77)\end{array}$ & $\begin{array}{c}25 \\
(86)\end{array}$ \\
\hline 5. & $\begin{array}{l}\text { Memberi } \\
\text { tanggapan } \\
\text { terhadap pendapat } \\
\text { kelompok lain }\end{array}$ & $\begin{array}{c}16 \\
(53)\end{array}$ & $\begin{array}{c}26 \\
(87)\end{array}$ & $\begin{array}{l}26 \\
90)\end{array}$ \\
\hline 6. & $\begin{array}{l}\text { Mempresentasikan } \\
\text { hasil kerja } \\
\text { kelompoknya }\end{array}$ & $\begin{array}{c}24 \\
(80)\end{array}$ & $\begin{array}{l}27 \\
(90)\end{array}$ & $\begin{array}{c}29 \\
(100)\end{array}$ \\
\hline 7. & $\begin{array}{l}\text { Membuat } \\
\text { kesimpulan } \\
\text { (mencatat hasi } \\
\text { diskusi kelompok) }\end{array}$ & $\begin{array}{c}29 \\
(97)\end{array}$ & $\begin{array}{c}29 \\
(100)\end{array}$ & $\begin{array}{c}29 \\
(100)\end{array}$ \\
\hline & Jumlah Siswa & 30 & 30 & 29 \\
\hline
\end{tabular}

Tabel 6. Data Jumlah Siswa yang Tuntas Pada Siklus II

\begin{tabular}{|c|c|c|c|c|c|}
\hline \multirow{2}{*}{ Siklus } & \multicolumn{2}{|c|}{$\begin{array}{c}\text { Siswa Mencapai } \\
\text { Nilai } \geq 70\end{array}$} & \multicolumn{2}{c|}{$\begin{array}{c}\text { Siswa } \\
\text { Mencapai } \\
\text { Nilai <70 }\end{array}$} & $\begin{array}{c}\text { Rata- } \\
\text { rata }\end{array}$ \\
\cline { 2 - 6 } & Angka & Persen & \multicolumn{2}{|c|}{ Angka } & Persen \\
\hline \multirow{2}{*}{ II } & 23 & 82,14 & 5 & $\begin{array}{c}17,8 \\
6\end{array}$ & 84,07 \\
\hline
\end{tabular}

Berdasarkan hasil refleksi siklus I dan refleksi siklus II dapat dilihat telah terjadi peningkatan kemampuan pemecahan masalah matematika dan aktivitas belajar siswa dengan penerapan pembelajaran berdasarkan masalah. Berikut ini akan dijelaskan pembahasan dari masing-masing variabel yang diteliti tersebut.

Aktivitas mengerjakan LKS yang diberikan guru berada pada interpretasi sangat baik $(81 \%$ - 100\%). Siswa telah aktif secara bersama-sama mengerjakan tugas atau latihan yang diberikan. Hal ini sesuai dengan indikator ketujuh dari Sardiman (2016), yaitu keterlibatan mental siswa di dalam pembelajaran yang ditunjukkan melalui keberadaan siswa dalam tugas. Pada akhir pembelajaran juga menunjukkan peningkatan aktivitas positif siswa yaitu membuat atau mencatat kesimpulan. Aktivitas siswa yang mengalami peningkatan juga terjadi pada mengajukaan pertanyaan kepada guru/kelompok lain, menjawab pertanyaan guru, berdiskusi dengan teman satu kelompok berdiskusi atau terlibat dalam diskusi kelompok, mengeluarkan ide/pendapat yang relevan dengan materi yang dipelajari. Aktivitas ini telah berada pada interpretasi baik $(61 \%$ - 80\%). Aktivitas ini menurut Nasution (2011) termasuk pada listening activities (diskusi) dan oral activities (mengeluarkan pendapat, mengadakan interview, diskusi).

Aktivitas memberi tanggapan terhadap pendapat kelompok lain, memberi bantuan kepada teman yang kesulitan dalam memahami dan menentukan cara menyelesaikan masalah, mengajukan pertanyaan kepada guru atau teman, aktivitas memberi jawaban/tanggapan tentang pertanyaan teman atau guru, juga mengalami peningkatan. Aktivitas ini menurut Hudoyo (1980) memperlihatkan bahwa guru tidak hanya membiarkan siswa belajar sendiri, siswa diajak untuk meningkatkan aktivitas mencari, bertanya, menalar bahkan menebak, menjawab, dan mendebat.

Hal ini menunjukkan bahwa siswa menyukai pembelajaran matematika melalui model pembelajaran berdasarkan masalah. Karena menurut Sardiman (2016) pembelajaran akan berhasil apabila disertai dengan rasa gembira. Jika siswa gembira mereka akan tetap di kelas, jika tidak, mereka akan keluar.

Terjadinya peningkatan aktivitas siswa dapat diinterpretasikan bahwa ternyata pembelajaran dengan menerapkan pembelajaran matematika melalui model pembelajaran berdasarkan masalah ini dapat meningkatkan aktivitas siswa dalam mata pelajaran matematika kelas X.3 SMA Negeri 1 Pekanbaru. Secara efektif, pembelajaran ini dapat menumbuhkan sikap positif siswa, menumbuhkan sikap kompetitif antar siswa, serta meningkatkan rasa percaya diri siswa. Secara psikomotorik pembelajaran ini juga dapat membiasakan siswa untuk 
mengaktualisasi potensi yang dimilikinya dalam bentuk keterampilan berdiskusi, presentasi, beragumentasi, dan yang terpenting menumbuhkembangkan keterampilan memecahkan masalah. Jadi secara umum, aktivitas kelas yang dicapai telah sesuai dengan apa yang diharapkan.

Pada siklus I dan II terjadi peningkatan kemampuan pemecahan masalah matematika siswa kelas X.3 SMA Negeri 1 Pekanbaru melalui model pembelajaran berdasarkan masalah. Data tersebut menunjukkan bahwa persentase siswa yang telah mencapai nilai Kriteria Ketuntasan Minimal 70 mengalami peningkatan sebesar 20,85\%. Terjadinya peningkatan ini disebabkan siswa mampu menemukan konflik dan mampu menyelesaikan permasalahan yang dihadapinya..

Dengan penerapan pembelajaran matematika melalui model pembelajaran berdasarkan masalah, siswa mempunyai keinginan untuk menguasai materi sebelum materi itu dipelajari di kelas, karena masalah yang diberikan akan didiskusikan antar kelompok akibatnya menimbulkan kompetisi untuk menjadi yang terbaik, sehingga tiap kelompok mempunyai keinginan untuk dapat tampil dan menjawab semua pertanyaan yang timbul sewaktu diskusi.

Lembar kerja siswa yang memuat soalsoal pemecahan masalah yang menjadi dasar sekaligus sumber belajar dalam pembelajaran memperlihatkan pengaruh sangat positif pada peningkatan kemampuan pemecahan masalah siswa. Ini berarti siswa telah memanfaatkan sumber belajar dengan baik dan mampu bekerjasama dalam kelompoknya untuk memahami materi secara bersama. Peningkatan kemampuan pemecahan masalah matematika yang terjadi pada siswa menandakan bahwa siswa memiliki kemampuan setelah mendapatkan pengalaman belajar. Dalam kaitan ini Nana Sudjana (2011) menyatakan bahwa hasil belajar adalah kemampuan yang dimiliki siswa setelah ia menerima pengalaman belajarnya.

Dengan pembelajaran berdasarkan masalah kemampuan siswa bernalar, mengaitkan masalah dengan pengetahuan yang dimilikinya dapat ditingkatkan. Kusumah dalam Lestari (2016) mengatakan bahwa belajar pemecahan masalah pada hakekatnya adalah belajar berpikir (learning to think) atau belajar bernalar (learning to reason), yaitu berpikir atau bernalar mengaplikasikan pengetahuanpengetahuan yang telah diperoleh sebelumnya untuk memecahkan masalah-masalah baru yang belum pernah dijumpai. Selain itu Menurut Arends (dalam Trianto 2009) menyatakan Pembelajaran berdasarkan masalah bertujuan untuk mengembangkan inkuiri dan keterampilan berpikir tingkat tinggi, mengembangkan kemandirian dan percaya diri. Terjadinya peningkatan kemampuan pemecahan masalah siswa dan terdapatnya lebih dari $75 \%$ siswa mencapai ketuntasan, berarti pembelajaran ini telah sesuai dengan yang diharapkan.

Berdasarkan hasil observasi dan tes hasil belajar siklus II peneliti bersama observer mengadakan refleksi terhadap pelaksanaan tindakan pada siklus II. Dari analisis data hasil pengamatan terlihat bahwa aktivitas mengerjakan LKS yang diberikan dan aktivitas mengajukan pertanyaan kepada guru/kelompok ini telah mencapai kategori sangat baik. Aktivitas lain juga mengalami peningkatan meski ada aktivitas berdiskusi dengan teman satu kelompok masih mencapai kategori baik. Pada siklus II ini siswa yang memberi tanggapan terhadap pendapat kelompok tidak lagi terpusat pada satu atau dua orang anggota kelompok, tetapi hampir semua anggota kelompok berperan aktif dalam pembelajaran di kelas. Kemampuan pemecahan masalah siswa pada siklus II mengalami peningkatan, baik pada aspek memahami masalah, memecahkan masalah, maupun menyelesaikan masalah dengan jawaban benar dibandingkan dengan siklus I. Siswa telah mengalami peningkatan pada kemampuan pemecahan masalah yang ditunjukkan pada tes hasil belajar pemecahan masalah siklus II. Persentase jumlah siswa yang tuntas telah mencapai $82,14 \%$. Dari refleksi siklus II diperoleh siswa yang telah mencapai hasil belajar di atas atau sama dengan KKM sebanyak $82,14 \%$ atau 23 siswa dari 31 siswa. Hal ini membuktikan bahwa penelitian yang dilaksanakan telah mencapai tujuan penelitian yang ditetapkan. Dalam pembelajaran di kelas, telah terjadi peningkatan aktivitas belajar dan suasana kompetisi membuat siswa ingin kelompoknya menjadi yang terbaik. Tiap anggota kelompok memperlihatkan peningkatan aktivitas atau terlibat dalam diskusi kelompok maupun diskusi kelas. Hal ini menunjukkan 
bahwa aktivitas siswa dalam pembelajaran matematika melalui model PBM telah mencapai hasil yang optimal sesuai dengan yang diharapkan. Sehingga peneliti bersama observer menganggap penelitian ini telah berhasil dan berhenti pada siklus II.

\section{SIMPULAN}

Berdasarkan hasil analisis terhadap berbagai data dalam penelitian ini dapat disimpulkan bahwa Penerapan pembelajaran matematika melalui model PBM dapat meningkatkan aktivitas dan kemampuan pemecahan masalah matematika siswa kelas X.3 SMA Negeri 1 Pekanbaru pada materi sistem persamaan linear dan pertidaksamaan satu variabel. Aktivitas mengerjakan LKS, mengajukan pertanyaan kepada guru/teman, menjawab pertanyaan guru/teman, mempresentasikan hasil kerja kelompok dan membuat kesimpulan, mencapai kategori baik sekali. Aktivitas berdiskusi dengan teman satu kelompok dan memberi tanggapan terhadap pendapat kelompok lain mencapai kategori baik. Kemampuan pemecahan masalah matematika siswa, baik pada pemahaman masalah, pemecahan masalah, maupun menjawab masalah telah mencapai hasil yang diharapkan. Tes hasil belajar kemampuan pemecahan masalah matematika siswa yang telah mencapai KKM meningkat dari $61,30 \%$ menjadi $82,14 \%$.

\section{DAFTAR PUSTAKA}

Arikunto, S., Suhardjono, dan Supardi. (2012). Penelitian Tindakan Kelas. Jakarta: Bumi Aksara

Depdiknas. (2006). Salinan Lampiran Permendiknas No. 22 Tentang Standar Isi. Jakarta: Depdiknas

Hudoyo, H. (1980). Teori Dasar Belajar Mengajar Matematika. Jakarta Departemen Pendidikan dan Kebudayaan.
Lestari, W.D. (2016). Penerapan Pembelajaran Kooperatif Tipe Group Investigation Berbantuan Proyek Terhadap Kemampuan Pemecahan Masalah Matematis Siswa SMP. Jurnal Matematika dan Pendidikan Matematika, 1(2), 154 - 164

Nasution, S. (2011). Berbagai Pendekatan dalam Proses belajar Mengajar. Edisi Pertama. Jakarta: Bumi Aksara.

Rohmawati, A. (2015). Efektivitas Pembelajaran. Jurnal Pendidikan Usia Dini, 9(1), 15 - 32

Rusman. (2010). Model-model Pembelajaran: Mengembangkan profesionalisme Guru. Jakarta: PT. Raja Grafindo Persada.

Sardiman, A.M. (2016). Interaksi dan Motivasi Belajar Mengajar. Jakarta: Raja Grafindo Persada

Sudjana, N. (2011). Penilaian Hasil Proses Belajar Mengajar. Bandung: PT Remaja Rosdakarya

Suherman, E., dkk. (2003). Strategi Pembelajaran Matematika Kontemporer. Bandung: JICA-UPI

Sukadewi, N.K.A., dan Sumaryani, N.P. (2016). Pengaruh Model Pembelajaran Talking Stick Berbantuan Mind Map Terhadap Hasil Belajar Biologi. Emasains, 5(1), 19 27

Szetela, W., dan Nicol, C. (1992). Evaluating Problem Solving in Mathematics. Educational Leadership, 5, 42-45.

Trianto. (2009). Mendesain Model Pembelajaran Inovatif-Progresif. Jakarta: Kencana Pranada Media Group 